Article

\title{
Comparison of Efficiency-Enhanced Management and Conventional Management of Irrigation and Nitrogen Fertilization in Cotton Fields of Northwestern China
}

\author{
Ping Wang ${ }^{1}$, Zhenyong Zhao ${ }^{1,2}$, Lei Wang ${ }^{1,2}$ and Changyan Tian ${ }^{1,2, *}$ \\ 1 State Key Laboratory of Desert and Oasis Ecology, Xinjiang Institute of Ecology and Geography, \\ Chinese Academy of Sciences, Urumqi 830011, China; wangping@ms.xjb.ac.cn (P.W.); \\ zhaozhy@ms.xjb.ac.cn (Z.Z.); egiwang@ms.xjb.ac.cn (L.W.) \\ 2 University of Chinese Academy of Sciences, Beijing 100049, China \\ * Correspondence: tianchy@ms.xjb.ac.cn; Tel.: +86-991-7823189
}

\section{check for} updates

Citation: Wang, P.; Zhao, Z.; Wang, L.; Tian, C. Comparison of EfficiencyEnhanced Management and Conventional Management of Irrigation and Nitrogen Fertilization in Cotton Fields of Northwestern China. Agriculture 2021, 11, 1134. https://doi.org/10.3390/ agriculture11111134

Academic Editors:

Ciro Antonio Rosolem

Received: 22 September 2021 Accepted: 10 November 2021 Published: 12 November 2021

Publisher's Note: MDPI stays neutral with regard to jurisdictional claims in published maps and institutional affiliations.

Copyright: (c) 2021 by the authors. Licensee MDPI, Basel, Switzerland. This article is an open access article distributed under the terms and conditions of the Creative Commons Attribution (CC BY) license (https:// creativecommons.org/licenses/by/ $4.0 /)$.

\begin{abstract}
Excessive application of nitrogen fertilizers and improper methods of irrigation under conventional management are common problems in the cotton fields of northwestern China. Efficiencyenhanced management, based on the water and nitrogen dynamics and crop requirements, has been used as a valuable strategy in different crops. The present study aimed to compare efficiencyenhanced management and conventional management of irrigation and nitrogen fertilization in the cotton fields at the Junggar Basin (Shihezi) and Tarim Basin (Cele) of northwestern China. Compared with conventional management, efficiency-enhanced management reduced the amount of $\mathrm{N}$ fertilizer by $41 \%$ in Cele and $44 \%$ in Shihezi, and the irrigation quantity by $35 \%$ in Cele and $24 \%$ in Shihezi. However, the cotton yield under efficiency-enhanced management was similar to that found under conventional management at both the experimental sites. The efficiency-enhanced management increased the water-use efficiency (WUE) and reduced the residual soil mineralizable $\mathrm{N}\left(\mathrm{N}_{\min }\right)$ and apparent $\mathrm{N}$ losses. This study indicated that efficiency-enhanced management can significantly enhance the utilization efficiency of irrigation water and $\mathrm{N}$ fertilizers for cotton production in the fields of northwestern China.
\end{abstract}

Keywords: cotton; efficiency-enhanced management; nitrogen; irrigation; nitrogen balance; WUE

\section{Introduction}

Xinjiang is one of the largest and high-yielding areas of cotton in China. The shortage of water due to the region's arid nature and climate change have become increasingly serious [1]. A large amount of arable land has been abandoned due to lack of water. Currently, increased water input and nutrient input are the two major approaches used to obtain higher yield. Drip irrigation is the primary irrigation system used to combat the water crisis, while flood irrigation is still prevalent in farmers' small-scale cotton fields in southern Xinjiang. However, extensive irrigation, especially flood irrigation, decreases water-use efficiency (WUE). Another major approach used in this area to promote cotton production is nitrogen $(\mathrm{N})$ fertilization. The recommended $\mathrm{N}$ fertilizer rate in Xinjiang $\left(240 \mathrm{~kg} \mathrm{ha}^{-1}\right)$ [2] is double the average used in the USA $\left(105 \mathrm{~kg} \mathrm{~N} \mathrm{ha}^{-1}\right)$ [3]. The excessive use of $\mathrm{N}$ fertilizers reduces the $\mathrm{N}$ recovery $[4,5]$ without any change in yield [6,7]. Moreover, excessive urea use and heavy irrigation by cotton farmers can easily lead to nitrate leaching losses [8,9]. Therefore, there is an urgent need to develop an efficiency-enhanced production strategy, including efficiency-enhanced irrigation and efficiency-enhanced $\mathrm{N}$ fertilization, for the high-yield cotton system in Xinjiang.

Several studies have analyzed the effects of different $\mathrm{N}$ fertilization methods on factors, such as crop N uptake [10-12], yield [13,14], crop N status [15-17], and fertilizer effect models [18-20]. Researchers have also evaluated the effects of reasonable irrigation 
measures, including reasonable irrigation index [21], reasonable irrigation schedules and methods $[22,23]$, and coupling water and fertilizer $[7,24]$ on cotton. These earlier findings provided a scientific basis for water and $\mathrm{N}$ management to promote cotton production in Xinjiang. However, no research has focused on water and $\mathrm{N}$ dynamics in the soil-plant system during the cotton-growing season. An understanding of the water and $\mathrm{N}$ status will further modify the management measures and provide an ideal situation.

The methods-based approach on soil nitrate- $\mathrm{N}$ tests have been used as a valuable tool for determining proper $\mathrm{N}$ fertilizer rates for different crops [25-27]. The previous researchers hypothesized that the efficiency of $\mathrm{N}$ fertilization could be enhanced by synchronizing fertilizer application with the plant requirement. Therefore, the synchronization of soil $\mathrm{N}$ supply (mineralizable $\mathrm{N}$ in root layer), $\mathrm{N}$ fertilizer application rates, and crop's $\mathrm{N}$ demand should improve $\mathrm{N}$-use efficiency and reduce fertilizer $\mathrm{N}$ losses.

Thus, the present study compared efficiency-enhanced management and conventional management of irrigation and $\mathrm{N}$ fertilization in the cotton fields of northwestern China. Under efficiency-enhanced management, water and $\mathrm{N}$ fertilizers were applied in the Xinjiang cotton fields by assessing the soil water and $\mathrm{N}$ dynamics in the cotton root layer. The study analyzed and compared the effects of efficiency-enhanced water and nitrogen management strategy on cotton dry matter and yield, water-use efficiency (WUE), and $\mathrm{N}$ balance with the traditional management strategy. In the efficiency-enhanced $\mathrm{N}$ management strategy, cotton $\mathrm{N}$ demand (dependent on cotton target yield) and soil available $\mathrm{N}$ content (soil $\mathrm{N}_{\min }$ test) before irrigation were tested to synchronize soil $\mathrm{N}$ supply ( $\mathrm{N}_{\min }$ in root layer), fertilizer $\mathrm{N}$ application, and cotton $\mathrm{N}$ demand. Meanwhile, soil moisture before irrigation was monitored, and the plant-available soil water (PASW) was maintained between $45 \%$ and $90 \%$ in the efficiency-enhanced irrigation strategy.

\section{Materials and Methods}

\subsection{Site Description}

The field experiments were conducted in the high-yielding cotton belt of southern and northern Xinjiang. One field experiment was conducted in Cele County $\left(80^{\circ} 13^{\prime} \mathrm{E}\right.$, $35^{\circ} 17^{\prime} \mathrm{N}$ ), located at the south edge of the Tarim Basin. During the growing seasons, the mean maximum and mean minimum temperatures were $34^{\circ} \mathrm{C}$ and $14^{\circ} \mathrm{C}$, respectively. The relative humidity ranged from $18 \%$ to $68 \%$, and the total amount of precipitation was $55.3 \mathrm{~mm}$. The second field experiment was conducted in Shihezi County $\left(86^{\circ} 02^{\prime} \mathrm{E}\right.$, $44^{\circ} 18^{\prime} \mathrm{N}$ ), located at the south edge of the Junggar Basin. During the growing seasons, the mean maximum and mean minimum temperatures were $35^{\circ} \mathrm{C}$ and $17^{\circ} \mathrm{C}$, respectively. The relative humidity ranged from $17 \%$ to $77 \%$, and the total amount of precipitation was $77.1 \mathrm{~mm}$. The physical and chemical properties of the soils $(0-30 \mathrm{~cm})$ of the two experimental sites before sowing are shown in Table 1.

Table 1. Physical and chemical properties of the $0-30 \mathrm{~cm}$ soil layer of the experimental sites in Xinjiang.

\begin{tabular}{ccc}
\hline Characteristics & Cele & Shihezi \\
\hline Soil texture & Fine Sand & Sandy Loam \\
Bulk density $\left(\mathrm{g} \mathrm{cm}^{-3}\right)$ & 1.38 & 1.32 \\
$\mathrm{pH}(1: 5)$ & 8.10 & 7.94 \\
Organic matter $\left(\mathrm{O} . \mathrm{M}, \mathrm{g} \mathrm{kg}^{-1}\right)$ & 3.07 & 10.81 \\
Total nitrogen $\left(\mathrm{N}, \mathrm{g} \mathrm{kg}^{-1}\right)$ & 0.36 & 0.78 \\
$\mathrm{~N}_{\text {min }}\left(\mathrm{NO}_{3}^{-}-\mathrm{N}+\mathrm{NH}_{4}^{+}-\mathrm{N}_{\mathrm{mg} \mathrm{kg}}^{-1}\right)$ & 9.29 & 22.40 \\
Available phosphorus $\left(\mathrm{Olsen}-\mathrm{P}_{\mathrm{mg} \mathrm{kg}}^{-1}\right)$ & 25.21 & 30.06 \\
Available potassium $\left(\mathrm{K}, \mathrm{mg} \mathrm{kg}^{-1}\right)$ & 153.10 & 188.57 \\
\hline
\end{tabular}

\subsection{Experimental Design}

The cotton (Gossypium hirsutum) cultivars Xinluzao12 and Xinluzao45 were used for the experiments in Cele and Shihezi, respectively. The cotton seeds were sown on 12 April in Cele and 21 April in Shihezi at a row spacing of $40 \mathrm{~cm}$ and a pot distance of $12.5 \mathrm{~cm}$. 
Approximately 273,000 plants per hectare were maintained in Cele and 200,000 plants per hectare in Shihezi.

Irrigation and $\mathrm{N}$ fertilization were the two treatment factors of this experiment. Two methods of irrigation were employed: conventional irrigation and efficiency-enhanced irrigation. Under the conventional irrigation, flood irrigation was completed five times during the growth period, with $660 \mathrm{~mm}$ of (cumulative) irrigation water in Cele, while drip irrigation was done seven times during the growth period, with $525 \mathrm{~mm}$ (cumulative) of irrigation water in Shihezi. These methods represented the common irrigation practice in the areas of the experimental county. Under the efficiency-enhanced irrigation, the timing and quantity of irrigation were determined after monitoring the soil water status in the root layer using the time-domain reflectometry (TDR) probes. The PASW was maintained between $45 \%$ and $90 \%$ in both sites. Meanwhile, three $\mathrm{N}$ fertilization treatments were employed: None-N fertilization (NonN), conventional fertilization (ConN), and efficiencyenhanced $\mathrm{N}$ fertilization (EEN). Under None-N treatment used as a control, no $\mathrm{N}$ fertilizer was applied during the entire growing season. Under ConN, $123 \mathrm{~kg} \mathrm{ha}^{-1} \mathrm{~N}$ (urea) was applied as base fertilizer (incorporated after broadcasting), and $309 \mathrm{~kg} \mathrm{ha}^{-1} \mathrm{~N}$ (urea) was used as topdressing (irrigation after broadcasted) at budding, early flowering, and peak flowering stages separately in Cele. This method represented the farmer's practice in the areas of the experimental site. In the Shihezi site, $345 \mathrm{~kg} \mathrm{ha}^{-1}$ of fertilizer was applied in total; $\mathrm{N}$ fertilizer (urea) was split-applied together with irrigation water via the surface drip system seven times $\left(34.5,34.5,34.5,69,69,69\right.$, and $\left.34.5 \mathrm{~kg} \mathrm{~N}^{-1}\right)$ during the growing season. Under efficiency-enhanced $\mathrm{N}$ fertilization, $\mathrm{N}$ fertilization was determined based on the plant $\mathrm{N}$ demand at different growth stages. Before each irrigation, soil $\mathrm{N}_{\min }$ was analyzed. Next, the rate of $\mathrm{N}$ fertilizer was determined based on the $\mathrm{N}_{\min }$ target value and the measured $\mathrm{N}_{\min }$ value. The steps followed in efficiency-enhanced $\mathrm{N}$ fertilization were as follows: the targets yield was determined based on the average yield of the test site over the past five years. In this study, both the experiment sites' target lint yield was $2250 \mathrm{~kg} \mathrm{ha}^{-1}$; next, the $\mathrm{N}$ demand of cotton at different growth stages under the target yield was estimated as reported earlier [28]; the soil $\mathrm{N}_{\min }$ target value of the growth stage was determined by multiplying the $\mathrm{N}$ demand of cotton at a specific growth stage with the factor 1.15 as follows:

$$
\text { Soil } \mathrm{N}_{\min } \text { target value }\left(\mathrm{kg} \mathrm{N} \mathrm{ha}^{-1}\right)=\mathrm{N} \text { demand }\left(\mathrm{kg} \mathrm{N} \mathrm{ha}^{-1}\right) \times 1.15
$$

Finally, the rate of $\mathrm{N}$ fertilizer at a particular stage of growth was determined by subtracting the measured soil $\mathrm{N}_{\min }$ at the beginning of that growth stage from the $\mathrm{N}_{\text {min }}$ target value as follows:

$\mathrm{N}$ fertilizer rate $\left(\mathrm{kg} \mathrm{N} \mathrm{ha}^{-1}\right)=$ Soil $\mathrm{N}_{\min }$ target value of the stage $\left(\mathrm{kg} \mathrm{N} \mathrm{ha}^{-1}\right)-\mathrm{N}_{\min }$ at the beginning of that growth stage $\left(\mathrm{kg} \mathrm{N}^{-1}\right)$

The experiment was conducted in a randomized complete block design with three replicates; the area of each replicate plot was $8 \times 8 \mathrm{~m}$. The details on $\mathrm{N}$ fertilization and irrigation amount were shown in Tables 2 and 3. All plots were fertilized with $65.5 \mathrm{~kg}$ $\mathrm{P} \mathrm{ha}^{-1}$ (triple superphosphate) and $75 \mathrm{~kg} \mathrm{~K} \mathrm{ha}^{-1}$ (potassium sulfate) as a base fertilizer before sowing. 
Table 2. Irrigation amount $(\mathrm{mm})$ under different irrigation managements of two experimental sites.

\begin{tabular}{|c|c|c|c|c|c|c|c|c|c|}
\hline \multirow{2}{*}{ Treatments } & \multirow{2}{*}{ Basal } & \multicolumn{7}{|c|}{ Topdressing } & \multirow{2}{*}{ Total } \\
\hline & & 1st & 2nd & 3rd & 4th & 5 th & 6th & 7th & \\
\hline \multicolumn{10}{|c|}{ Cele } \\
\hline ConI & 0 & 135 & 135 & 0 & 135 & 0 & 135 & 120 & 660 \\
\hline EEI & 0 & 71 & 55 & 68 & 68 & 58 & 52 & 55 & $427( \pm 31)$ \\
\hline \multicolumn{10}{|c|}{ Shihezi } \\
\hline ConI & 0 & 75 & 75 & 75 & 75 & 75 & 75 & 75 & 525 \\
\hline EEI & 0 & 65 & 52 & 64 & 67 & 50 & 62 & 39 & $399( \pm 26)$ \\
\hline
\end{tabular}

"ConI" and "EEI" represent conventional irrigation and efficiency-enhanced irrigation, respectively.

Table 3. Nitrogen rates $\left(\mathrm{kg} \mathrm{ha}^{-1}\right)$ under different nitrogen fertilization managements of two experimental sites.

\begin{tabular}{|c|c|c|c|c|c|c|c|c|c|c|}
\hline \multirow{2}{*}{\multicolumn{2}{|c|}{ Treatments }} & \multirow{2}{*}{ Basal } & \multicolumn{7}{|c|}{ Topdressing } & \multirow{2}{*}{ Total } \\
\hline & & & 1st & 2nd & $3 r d$ & 4th & 5 th & 6th & 7 th & \\
\hline \multicolumn{11}{|c|}{ Cele } \\
\hline \multirow{3}{*}{ ConI } & NonN & 0 & 0 & 0 & 0 & 0 & 0 & 0 & 0 & 0 \\
\hline & ConN & 123 & 0 & 69 & 0 & 135 & 0 & 105 & 0 & 432 \\
\hline & EEN & 30 & 0 & 36 & 0 & 57 & 0 & 103 & 55 & $281( \pm 49)$ \\
\hline \multirow{3}{*}{ EEI } & NonN & 0 & 0 & 0 & 0 & 0 & 0 & 0 & 0 & 0 \\
\hline & ConN & 123 & 0 & 69 & 0 & 135 & 0 & 105 & 0 & 432 \\
\hline & EEN & 30 & 0 & 36 & 50 & 87 & 0 & 53 & 0 & $256( \pm 28)$ \\
\hline \multicolumn{11}{|c|}{ Shihezi } \\
\hline \multirow{3}{*}{ ConI } & NonN & 0 & 0 & 0 & 0 & 0 & 0 & 0 & 0 & 0 \\
\hline & ConN & 0 & 34.5 & 34.5 & 34.5 & 69 & 69 & 69 & 34.5 & 345 \\
\hline & EEN & 0 & 0 & 26 & 35 & 56 & 43 & 40 & 17 & $217( \pm 45)$ \\
\hline \multirow{3}{*}{ EEI } & NonN & 0 & 0 & 0 & 0 & 0 & 0 & 0 & 0 & 0 \\
\hline & ConN & 0 & 34.5 & 34.5 & 34.5 & 69 & 69 & 69 & 34.5 & 345 \\
\hline & EEN & 0 & 0 & 33 & 29 & 38 & 34 & 35 & 22 & $191( \pm 32)$ \\
\hline
\end{tabular}

"NonN", "ConN", and "EEN" represent none nitrogen (N) fertilization, conventional N fertilization, and efficiencyenhanced $\mathrm{N}$ fertilization, respectively. "ConI" and "EEI" represent conventional irrigation and efficiency-enhanced irrigation, respectively.

\subsection{Measurement of Plant and Soil Parameters}

\subsubsection{Plant Dry Matter Accumulation and Nitrogen Content}

Sampling was initiated approximately 30 days after plant emergence. The entire plant was sampled periodically (every 14 days) throughout the growing season. Ten plants were sampled per plot at a time. A border of $140 \mathrm{~cm}$ was allowed for each sampling area in the front, back, and sides. Harvested plants were immediately separated into leaves, stems, and fruiting forms. No attempt was made to collect the shed leaves and fruits. Mature bolls were divided into lint, seeds, and burs. The bur fraction included squares, flowers, immature bolls, and burs from mature bolls. Plant parts were dried at $60{ }^{\circ} \mathrm{C}$, weighed, and ground to a fine powder, then passed through a $40 \mathrm{~mm}$ stainless steel sieve.

Approximately $0.3 \mathrm{~g}$ of each plant part (except for the lint) was weighed and added into a digestion solution (sulfuric acid, $\mathrm{H}_{2} \mathrm{SO}_{4}$; potassium sulfate, $\mathrm{K}_{2} \mathrm{SO}_{4}$; and mercuric sulfate, $\mathrm{HgSO}_{4}$ ), and the sample mixture was digested for $1 \mathrm{~h}$ at $160^{\circ} \mathrm{C}$ on a preheated block digester to allow the water to evaporate. Then, the temperature was increased to $380^{\circ} \mathrm{C}$, and the sample was maintained at this temperature for another $2.5 \mathrm{~h}$. The tubes were then allowed to cool, and the samples were diluted to $25 \mathrm{~mL}$ with ammonia-free water. The $\mathrm{N}$ content of the digest was measured using an Autoanalyzer (Bran Luebbe $\mathrm{GmbH}$, Norderstedt, Germany). 


\subsubsection{Seed Cotton Yield}

Seed cotton yield was determined at maturity by manually picking the seed cotton from each plot's yield-counting (unsampled) area.

\subsubsection{Soil Mineral Nitrogen Content}

Soil samples were collected to determine the mineral $N$ content $\left(N_{\min }\right)$ throughout the growing season. Approximately $60 \mathrm{~cm}$ deep soil cores were collected from each plot and separated into $0-30 \mathrm{~cm}$ and $30-60 \mathrm{~cm}$ parts. Meanwhile, the $60-120 \mathrm{~cm}$ soil samples were collected before sowing and after harvest to evaluate the possibility of nitrate $\left(\mathrm{NO}_{3}{ }^{-}\right)$leaching in the deeper soil. Soil samples were sieved, mixed, and extracted with a $0.01 \mathrm{~mol} \mathrm{~L}^{-1}$ calcium chloride $\left(\mathrm{CaCl}_{2}\right)$ solution. The ammonium-nitrogen $\left(\mathrm{NH}_{4}{ }^{+}-\mathrm{N}\right)$ and nitrate-nitrogen $\left(\mathrm{NO}_{3}{ }^{-}-\mathrm{N}\right)$ in the soil were analyzed by an Autoanalyzer.

\subsection{Data Analysis}

All data were analyzed using the one-way ANOVA in SAS (SAS Institute, Inc, Cary, $\mathrm{NC}$, USA, 2011). The mean values of dry matter accumulation, $\mathrm{WUE}$, and $\mathrm{N}_{\min }$ in the soil after harvest under the different $\mathrm{N}$ fertilization and irrigation treatments were compared using the least significant difference (LSD), at a 0.05 significance level.

The WUE was calculated by dividing seed cotton yield per unit of land area by the total irrigation amount [29] as follows:

$$
\text { WUE }\left(\mathrm{kg} \mathrm{ha}^{-1} \mathrm{~mm}^{-1}\right)=\text { Seed cotton yield }\left(\mathrm{kg} \mathrm{ha}^{-1}\right) / \text { Total irrigation amount }(\mathrm{mm})
$$

Apparent $\mathrm{N}$ mineralization during the cotton growing season was estimated by subtracting the initial extractable mineral soil $\mathrm{N}\left(\mathrm{N}_{\min }\right)$ in the $0-60 \mathrm{~cm}$ soil layer of the control plot before planting from the sum of the aboveground $\mathrm{N}$ uptake and residual soil $\mathrm{N}_{\min }$ at harvest in the same soil layer [30] as follows:

Apparent $\mathrm{N}$ mineralization $=$ Soil $\mathrm{N}_{\min }$ at harvest of no $\mathrm{N}$ treatment $\left(\mathrm{kg} \mathrm{ha}^{-1}\right)+\mathrm{N}$ uptake of no $\mathrm{N}$ treatment $\left(\mathrm{kg} \mathrm{ha}^{-1}\right)$

- Soil $\mathrm{N}_{\min }$ before sowing of no $\mathrm{N}$ treatment $\left(\mathrm{kg} \mathrm{ha}^{-1}\right)$

The $\mathrm{N}_{\min }$ concentration, soil bulk density, and soil water content were measured to determine the absolute $\mathrm{N}_{\min }$ content of the different soil layers. The total residual $\mathrm{N}_{\min }$ was calculated as a sum of the different soil layers.

\section{Results}

\subsection{Rate of Nitrogen Fertilization and Irrigation}

In Cele, efficiency-enhanced management based on the soil $\mathrm{N}_{\min }$ in the cotton root layer at different growth stages reduced the $\mathrm{N}$ fertilizer amount from $432 \mathrm{~kg} \mathrm{ha}^{-1}$ to $281 \mathrm{~kg} \mathrm{ha}^{-1}(35 \%)$ under conventional irrigation, and $256 \mathrm{~kg} \mathrm{ha}^{-1}(41 \%)$ under efficiencyenhanced irrigation (Table 3). In Shihezi, the $\mathrm{N}$ fertilizer amount was reduced from $345 \mathrm{~kg} \mathrm{ha}^{-1}$ to $217 \mathrm{~kg} \mathrm{ha}^{-1}$ (37\%) under conventional irrigation, and $191 \mathrm{~kg} \mathrm{ha}^{-1}(44 \%)$ under efficiency-enhanced irrigation. Taken together, the $\mathrm{N}$ fertilizer amount with efficiencyenhanced irrigation was $9 \%$ (Cele) to $12 \%$ (Shihezi) lower than conventional irrigation. In Cele, the efficiency-enhanced $\mathrm{N}$ fertilization dramatically reduced the amount of basal $\mathrm{N}$ fertilizer from $123 \mathrm{~kg} \mathrm{ha}^{-1}$ to $30 \mathrm{~kg} \mathrm{ha}^{-1}$. At the same time, it increased the amount of topdressing $\mathrm{N}$ fertilizer at the boll forming stage. In Shihezi, the efficiency-enhanced $\mathrm{N}$ fertilization approach reduced the amount of fertilizer applied at each top dressing.

Conventionally, single irrigation with $120-135 \mathrm{~mm}$ of water was used at Cele (Table 2). Efficiency-enhanced irrigation based on soil moisture monitoring using TDR probes reduced the single irrigation amount to $52-71 \mathrm{~mm}$, with two additional irrigations; the total amount of irrigation water was reduced from $660 \mathrm{~mm}$ to $427 \mathrm{~mm}$. Thus, efficiencyenhanced irrigation reduced the single irrigation amount and total irrigation amount, which increased the irrigation frequency. Meanwhile, the single irrigation amount under conventional drip irrigation in Shihezi was relatively large; efficiency-enhanced irrigation 
based on soil moisture monitoring reduced the total irrigation amount from $525 \mathrm{~mm}$ to $399 \mathrm{~mm}$.

\subsection{Dry Matter and Yield}

The analysis of dry matter and yield (Table 4) showed no significant differences in total dry matter and yield between the efficiency-enhanced $\mathrm{N}$ fertilization and the conventional $\mathrm{N}$ fertilization in both Cele and Shihezi; however, both were superior to None$\mathrm{N}$ fertilization treatment. In Cele, seed cotton yield under efficiency-enhanced irrigation was similar to conventional irrigation, while the proportion of vegetative parts (shoots and leaves) under efficiency-enhanced irrigation was significantly higher. Except under None-N fertilization, the efficiency-enhanced irrigation promoted the growth of stems and leaves but did not result in a yield increase. In contrast, the efficiency-enhanced irrigation and conventional irrigation treatments resulted in similar dry matter of stems and leaves and the yield of seed cotton in Shihezi.

Table 4. Effect of irrigation and nitrogen fertilization strategies on cotton dry matter accumulation $\left(\mathrm{t} \mathrm{ha}^{-1}\right)$.

\begin{tabular}{|c|c|c|c|c|c|c|}
\hline \multicolumn{2}{|c|}{ Treatments } & Shoots & Leaves & Burs & Seed Cotton & Total \\
\hline \multicolumn{7}{|c|}{ Cele } \\
\hline \multirow{3}{*}{ ConI } & NonN & $1.17 \mathrm{c}$ & $0.78 \mathrm{c}$ & $0.55 \mathrm{~b}$ & $2.44 \mathrm{~b}$ & $4.94 \mathrm{~b}$ \\
\hline & ConN & $2.63 \mathrm{~b}$ & $1.88 \mathrm{~b}$ & $1.40 \mathrm{a}$ & $4.88 \mathrm{a}$ & $10.79 \mathrm{a}$ \\
\hline & EEN & $2.43 \mathrm{~b}$ & $1.87 \mathrm{~b}$ & $1.56 \mathrm{a}$ & $4.65 \mathrm{a}$ & $10.51 \mathrm{a}$ \\
\hline \multirow{3}{*}{ EEI } & NonN & $1.48 \mathrm{c}$ & $1.04 \mathrm{c}$ & $0.62 b$ & $2.40 \mathrm{~b}$ & $5.54 b$ \\
\hline & ConN & $3.15 \mathrm{a}$ & $2.60 \mathrm{a}$ & $1.69 \mathrm{a}$ & $4.85 \mathrm{a}$ & $12.29 \mathrm{a}$ \\
\hline & EEN & $2.94 \mathrm{a}$ & $2.38 \mathrm{a}$ & $1.60 \mathrm{a}$ & $4.73 \mathrm{a}$ & $11.65 \mathrm{a}$ \\
\hline \multicolumn{7}{|c|}{ Shihezi } \\
\hline \multirow{3}{*}{ ConI } & NonN & $2.09 \mathrm{~b}$ & $1.76 \mathrm{~b}$ & $1.97 \mathrm{~b}$ & $4.05 \mathrm{~b}$ & $8.23 \mathrm{~b}$ \\
\hline & ConN & $2.73 \mathrm{a}$ & $2.22 \mathrm{a}$ & $2.63 \mathrm{a}$ & $6.18 \mathrm{a}$ & $13.01 \mathrm{a}$ \\
\hline & EEN & $2.69 a$ & $2.04 \mathrm{a}$ & $2.57 \mathrm{a}$ & $6.04 \mathrm{a}$ & $12.82 \mathrm{a}$ \\
\hline \multirow{3}{*}{ EEI } & NonN & $1.98 \mathrm{~b}$ & $1.87 \mathrm{~b}$ & $1.93 \mathrm{~b}$ & $3.90 \mathrm{~b}$ & $8.06 \mathrm{~b}$ \\
\hline & ConN & $2.70 \mathrm{a}$ & $2.15 \mathrm{a}$ & $2.48 \mathrm{a}$ & $6.06 \mathrm{a}$ & $12.03 \mathrm{a}$ \\
\hline & EEN & $2.67 \mathrm{a}$ & $2.13 \mathrm{a}$ & $2.51 \mathrm{a}$ & $5.91 \mathrm{a}$ & $12.31 \mathrm{a}$ \\
\hline
\end{tabular}

Mean values in each site column followed by the same letter are not significantly different (Duncan's multiple range test, $p<0.05)$. "NonN", "ConN", and "EEN" represent no nitrogen $(\mathrm{N})$ fertilization, conventional $\mathrm{N}$ fertilization, and efficiency-enhanced $\mathrm{N}$ fertilization, respectively. "ConI" and "EEI" represent conventional irrigation and efficiency-enhanced irrigation, respectively.

\subsection{Irrigation Water-Use Efficiency (WUE), Residual Soil Nitrogen Mineralization $\left(\mathrm{N}_{\min }\right)$, and Nitrogen Balance}

Efficiency-enhanced irrigation significantly increased the irrigation WUE by $53.9 \%$ in Cele and 29.0\% in Shihezi (Figure 1). Meanwhile, $\mathrm{N}$ fertilization enhanced the irrigation WUE when compared with no $\mathrm{N}$ treatment; however, no significant difference was observed between conventional $\mathrm{N}$ fertilization and efficiency-enhanced $\mathrm{N}$ fertilization. The soil $\mathrm{N}_{\min }$ in the 0-60 $\mathrm{cm}$ layer under conventional $\mathrm{N}$ fertilization and efficiency-enhanced $\mathrm{N}$ fertilization was significantly higher than None-N fertilization (Figure 2). The conventional $\mathrm{N}$ fertilization treatment increased the residual $\mathrm{N}_{\min }$ in the $60-120 \mathrm{~cm}$ soil layer, and the efficiency-enhanced $\mathrm{N}$ fertilization treatment decreased the residual $\mathrm{N}_{\min }$ significantly. Analysis of the $\mathrm{N}$ balance (Table 5) showed high $\mathrm{N}$ losses (179-294 $\mathrm{kg} \mathrm{ha}^{-1}$ ) due to a large amount of $\mathrm{N}$ fertilizer applied (345-432 $\mathrm{kg} \mathrm{ha}^{-1}$ ) under the conventional management system. Meanwhile, the efficiency-enhanced management approach significantly decreased the $\mathrm{N}$ losses $\left(43-87 \mathrm{~kg} \mathrm{ha}^{-1}\right)$. 

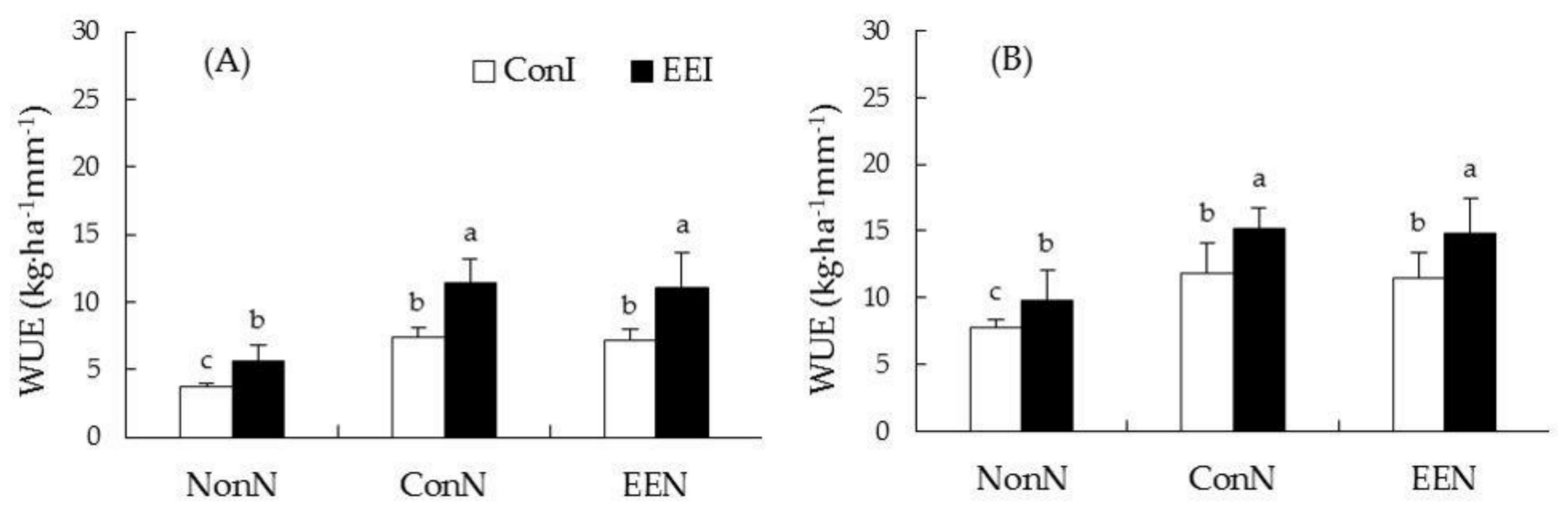

Figure 1. Effect of different irrigation and nitrogen fertilization strategies on water-use efficiency (WUE; $\left.\mathrm{kg} \mathrm{ha}^{-1} \mathrm{~mm}^{-1}\right)$. (A) represents the Cele site, and (B) represents the Shihezi site. "NonN", "ConN", and "EEN" represent no nitrogen (N) fertilization, conventional $\mathrm{N}$ fertilization, and efficiency-enhanced $\mathrm{N}$ fertilization, respectively. "ConI" and "EEI" represent conventional irrigation and efficiency-enhanced irrigation, respectively. The values (mean \pm s.e) sharing the same letter are not significantly different at $p<0.05$.
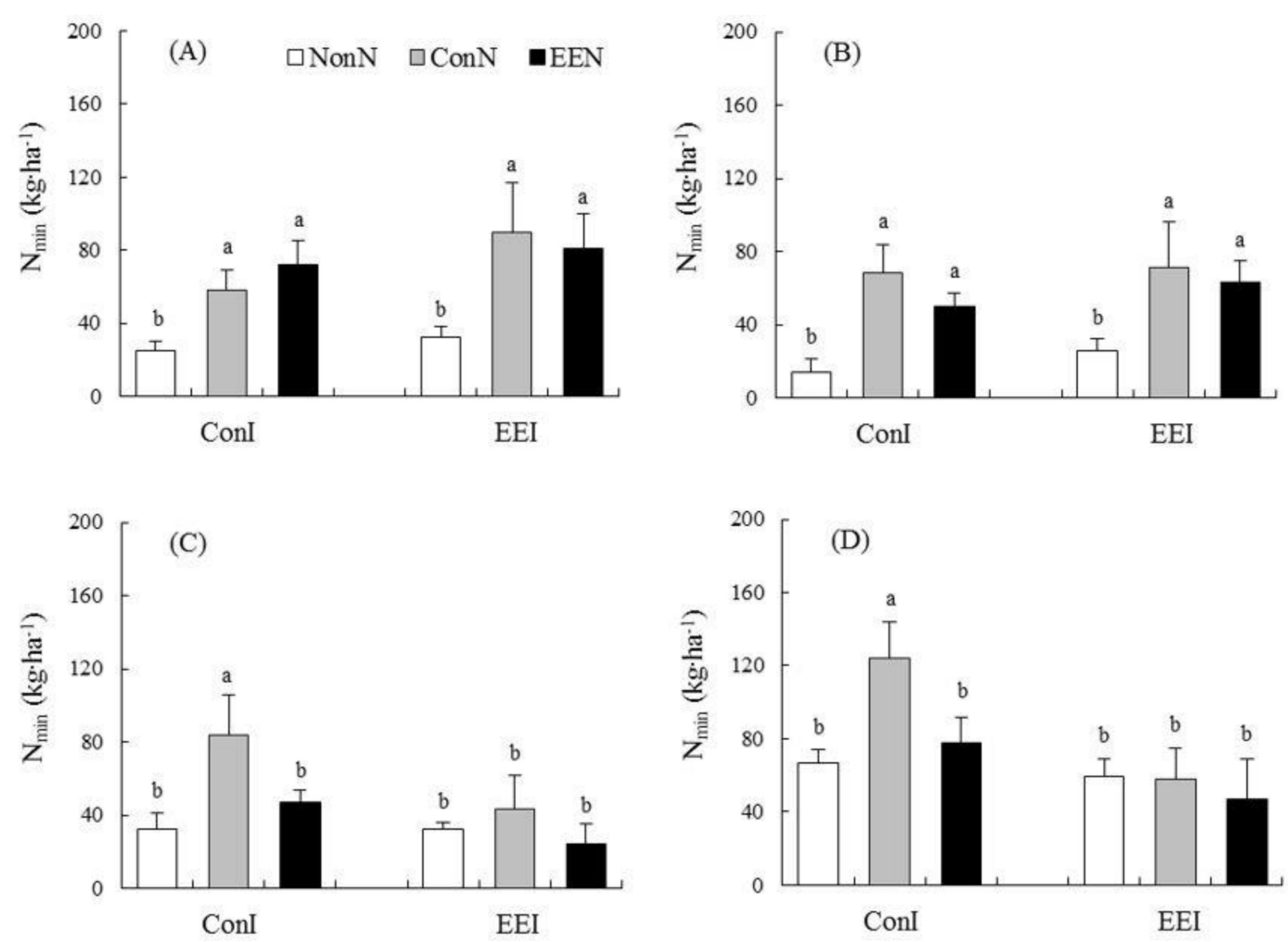

Figure 2. Soil mineralizable $\mathrm{N}\left(\mathrm{N}_{\min } ; \mathrm{kg} \mathrm{ha}^{-1}\right)$ in the $0-60 \mathrm{~cm}$ and $60-120 \mathrm{~cm}$ soil layers after cotton harvest. (A,C) represent 0-60 cm and 60-120 cm soil layers of Cele, respectively; (B,D) represent the 0-60 cm and 60-120 cm soil layers of Shihezi, respectively. "NonN", “ConN", and “EEN" represent none nitrogen (N) fertilization, conventional N fertilization, and efficiency-enhanced $\mathrm{N}$ fertilization, respectively. "ConI" and “EEI" represent conventional irrigation and efficiency-enhanced irrigation, respectively. The values (mean \pm s.e) sharing the same letter are not significantly different at $p<0.05$. 
Table 5. Nitrogen balance in cotton under different irrigation and nitrogen treatments.

\begin{tabular}{|c|c|c|c|c|}
\hline \multirow{2}{*}{ Parameter } & \multicolumn{2}{|c|}{ Cele } & \multicolumn{2}{|c|}{ Shihezi } \\
\hline & ConM & EEM & ConM & EEM \\
\hline \multicolumn{5}{|c|}{$\mathrm{N}$ input } \\
\hline $\begin{array}{l}\text { (1) } \mathrm{N} \text { supply }\left(\mathrm{kg} \mathrm{ha}^{-1}\right) \\
\text { (a) } \mathrm{N}_{\min } \text { in } 0-60 \mathrm{~cm} \text { before sowing } \\
\text { (b) } \mathrm{N} \text { fertilizer applied } \\
\text { (2) Apparent mineralization } \\
\text { Total } \mathrm{N} \text { supply }(=1+2)\end{array}$ & $\begin{array}{c}44 \\
432 \\
75 \\
551 \\
\end{array}$ & $\begin{array}{c}44 \\
256 \\
92 \\
392 \\
\end{array}$ & $\begin{array}{l}59 \\
345 \\
133 \\
537\end{array}$ & $\begin{array}{l}59 \\
191 \\
128 \\
378\end{array}$ \\
\hline \multicolumn{5}{|c|}{ N output } \\
\hline $\begin{array}{l}\text { (3) } \mathrm{N} \text { uptake by cotton }\left(\mathrm{kg} \mathrm{ha}^{-1}\right) \\
\text { (4) } \mathrm{N} \text { surplus } \\
\text { (a) } \mathrm{N}_{\text {min }} \text { in } 0-60 \mathrm{~cm} \text { after harvest } \\
\text { (b) Apparent } \mathrm{N} \text { losses }\end{array}$ & $\begin{array}{c}216 \\
335 \\
58 \\
294\end{array}$ & $\begin{array}{l}243 \\
149 \\
81 \\
87\end{array}$ & $\begin{array}{c}290 \\
247 \\
68 \\
179\end{array}$ & $\begin{array}{l}272 \\
106 \\
63 \\
43\end{array}$ \\
\hline
\end{tabular}

"ConM" and "EEM" represent conventional irrigation and $\mathrm{N}$ fertilization management and efficiency-enhanced irrigation and $\mathrm{N}$ fertilization management, respectively.

\section{Discussion}

Several researchers have analyzed the effects of water and $\mathrm{N}$ management on cotton [10,31]; however, the present study is the first to adopt efficiency-enhanced irrigation and $\mathrm{N}$ fertilizer application for cotton in the arid northwestern region of China based on the monitoring of soil water and $\mathrm{N}$ dynamics. In the present study, the amount of $\mathrm{N}$ applied was optimized based on real-time monitoring of soil $\mathrm{N}$ to match the cotton $\mathrm{N}$ demand and keep the residual $\mathrm{N}_{\min }$ at a reasonable range. Excessive $\mathrm{N}$ fertilizer used under conventional fertilization enhanced the growth of vegetative parts (shoots and leaves) with no increase in yield in Cele. Meanwhile, under efficiency-enhanced $\mathrm{N}$ fertilization, a dramatically reduced amount of $\mathrm{N}$ fertilizer (reducing basal fertilizer) was applied to cotton, which decreased the $\mathrm{N}$ losses and residual $\mathrm{N}_{\min }$ without a decrease in yield. Thus, the efficiency-enhanced $\mathrm{N}$ fertilization of the current study maintained a relatively high yield, reducing the environmental risk of $\mathrm{N}$ fertilization by decreasing the amount of fertilizer that enters environments. The analysis of the $\mathrm{N}$ balance revealed an imbalance between the $\mathrm{N}$ fertilizer application and the $\mathrm{N}$ losses. Therefore, the aim of high-yielding cotton field management should be to balance yield, resource-use efficiency, and environment. Typically, yield is the result of the interaction of water and fertilizer, field management, and other factors [31,32]; therefore, integrated management measures should be adopted to further improve the $\mathrm{N}$ fertilizer recovery and WUE, increasing the yield level.

In Cele, the soil is fine sand, with low water-holding capacity and deep groundwater (below $15 \mathrm{~m}$ ). Though the cotton plants were irrigated five times with $660 \mathrm{~mm}$ water, drought still affected the growth under conventional irrigation. Efficiency-enhanced irrigation improved the soil water condition and promoted vegetative growth; however, the excessive growth of vegetative parts might have restricted the growth of reproductive parts under high plant density. The last irrigation also delayed leaf fall under efficiency-enhanced irrigation. The results of the soil $\mathrm{N}_{\min }$ test showed (Figure 2) that the efficiency-enhanced irrigation reduced water leaching to deep soil in Cele, which slowed down the leaching of nitrate, and improved the moisture status of cotton. Meanwhile, though drip irrigation techniques in Shihezi have efficiently managed moisture use in cotton, the efficiency-enhanced irrigation further saved $24 \%$ of the irrigation water. Under drip irrigation in Shihezi, a large amount of $\mathrm{N}_{\min }$ was accumulated in the $60-120 \mathrm{~cm}$ soil layer in conventional irrigation and $\mathrm{N}$ fertilization management, indicating the $\mathrm{N}$ leaching under drip irrigation. Occasionally, farmers adopt extensive drip irrigation to prevent salt accumulation in the soil. However, excessive drip irrigation increases the risk of $\mathrm{N}$ leaching loss. Under efficiency-enhanced irrigation in both sites, the irrigation frequency and amount were manipulated by monitoring the soil water status to satisfy crop demand and save water. The efficiency-enhanced irrigation approach of this study indicates that the single irrigation amount under conventional irrigation exceeds the PASW of soil in the root layer, quickly leading to infiltration and subsequent wastage. Soil moisture monitoring showed that 
the irrigation interval was wide under conventional irrigation, especially in Cele, which resulted in soil moisture deficit around the roots. Compared with conventional irrigation, efficiency-enhanced irrigation saved about one-third of water without compromising yield at Cele, suggesting a huge potential to limit irrigation water used for cotton production under flood irrigation. Previously, Shen et al. (2013) reported a decrease in yield with excess water in northwestern China [21]. Therefore, to further optimize irrigation management, it is necessary to understand cotton's water requirement features.

Furthermore, the study's findings indicated that the efficiency-enhanced irrigation strategy might have reduced $\mathrm{N}$ losses, reducing the $\mathrm{N}$ fertilizer requirement in both sites. Thus, the water-fertilizer interaction effect probably played a significant role under the efficiency-enhanced irrigation and $\mathrm{N}$ fertilization management. The study also suggested that the dynamic monitoring of soil water and $\mathrm{N}$ status during the growth period would help optimize water and $\mathrm{N}$ application rates, as well as understand the interaction effects. Among the different techniques, drip irrigation has been popularized during the past decade for saving water and fertilizer. The drip irrigation technique accurately controls water and fertilizer input and is suitable for optimized water and fertilizer application. The study's findings suggested that even with ConI, it is feasible to achieve high yields with the efficient use of resources.

\section{Conclusions}

Irrigation water and $\mathrm{N}$ fertilizers are used in large amounts under conventional fertilizer management in Cele and Shihezi. In the present study, irrigation and $\mathrm{N}$ fertilization management based on real-time monitoring of soil $\mathrm{N}$ and water status significantly saved $\mathrm{N}$ fertilizer and irrigation water without compromising the yield. The efficiency-enhanced irrigation and $\mathrm{N}$ management increased irrigation WUE, and significantly reduced residual Nmin (0-120 cm soil) and apparent $\mathrm{N}$ losses when compared with the conventional irrigation and $\mathrm{N}$ fertilization management. In conclusion, the method described in this study is an agronomically sound and sustainable irrigation and $\mathrm{N}$ fertilization management strategy for cotton. The sites of this study (Cele and Shihezi) were located in arid regions of the temperate zone, where rainfall was scarce and crop growth mainly depended on irrigation. Such environmental conditions are typical in cotton growing regions around the world. Therefore, efficiency-enhanced management of this study can be used for reference in other cotton areas.

Author Contributions: Conceptualization, C.T. and P.W.; writing—original draft preparation, P.W.; writing—-review and editing, Z.Z., C.T. and L.W.; visualization, L.W.; project administration, L.W.; funding acquisition, Z.Z. All authors have read and agreed to the published version of the manuscript.

Funding: This study was financially supported by the Strategic Priority Research Program of the Chinese Academy of Sciences (Grant No. XDA2003010302), West Light Talent Program of the Chinese Academy of Sciences (Grant No. 2019-YDYLTD-001), and The National Natural Science Foundation of China (Grant No. 41171247).

Institutional Review Board Statement: Not applicable.

Informed Consent Statement: Not applicable.

Data Availability Statement: The data presented in this study are available on request from the corresponding author. The data are not publicly available due to privacy.

Conflicts of Interest: The authors declare no conflict of interest. 


\section{References}

1. Shen, X.; Zhang, J.; Sun, J. Optimal irrigation index for cotton drip irrigation under film mulching based on the evaporation from pan with constant water level. Chin. J. Appl. Ecol. 2013, 24, 3153-3161. (In Chinese with English Abstract)

2. Wang, H.; Wu, L.; Cheng, M.; Fan, J.; Zhang, F.; Zou, Y.; Chau, H.; Gao, Z.; Wang, X. Coupling effects of water and fertilizer on yield, water and fertilizer use efficiency of drip-fertigated cotton in northern Xinjiang, China. Field Crop Res. 2018, 219, 169-179. [CrossRef]

3. United States Department of Agriculture (USDA). 2019. Available online: https://www.ers.usda.gov/data-products/fertilizeruse-and-price/ (accessed on 29 June 2021).

4. Fang, W.; Li, L.; Xie, D.; Ma, Z.; Zhang, D.; Du, Y. Comparison of dry matter accumulation and N, P, K uptake and distribution in different organs and yield on hybrid cotton and conventional cotton. Plant Nutr. Fertil. Sci. 2009, 15, 1401-1406.

5. Stamatiadis, S.; Tsadilas, C.; Samaras, V.; Schepers, J.S.; Eskridge, K. Nitrogen uptake and N-use efficiency of Mediterranean cotton under varied deficit irrigation and $\mathrm{N}$ fertilization. Eur. J. Agron. 2016, 73, 144-151. [CrossRef]

6. Guo, J.; Wei, C.; Hou, Z.; Li, J. Effect of $\mathrm{N}$ rates on $\mathrm{N}$ uptake, accumulation and yield of cotton under drip irrigation and mulch. J. Arid Land Res. Environ. 2008, 22, 139-142.

7. Zonta, J.H.; Brandão, Z.N.; Sofiatti, V.; Bezerra, J.R.C.; Medeiros, J.C. Irrigation and nitrogen effects on seed cotton yield, water productivity and yield response factor in semi-arid environment. Aust. J. Crop Sci. 2016, 10, 118-126.

8. Dinnes, D.L.; Karlen, D.L.; Jaynes, D.B.; Kaspar, T.C.; Hatfield, J.L.; Colvin, T.S.; Gambardella, C.A. Nitrogen management strategies to reduce nitrate leaching in tile-drained midwestern soils. Agron. J. 2002, 94, 153-171. [CrossRef]

9. Good, A.G.; Shrawat, A.K.; Muench, D.G. Can less yield more? Is reducing nutrient input into the environment compatible with maintaining crop production? Trend Plant Sci. 2004, 9, 597-605. [CrossRef]

10. Robert, L.; Boman, R.; McFarl, M.; Bean, B.; Provin, T.; Hons, F. Nitrogen management in cotton. AgriLife Ext. $2009,1-9$.

11. Shah, A.N.; Iqbal, J.; Tanveer, M.; Yang, G.; Hassan, W.; Fahad, S.; Wu, Y. Nitrogen fertilization and conservation tillage: A review on growth, yield, and greenhouse gas emissions in cotton. Environ. Sci. Pollut. Res. 2016, 24, 2261-2272. [CrossRef]

12. Khan, A.; Tan, D.K.; Afridi, M.Z.; Luo, H.; Tung, S.A.; Ajab, M.; Fahad, S. Nitrogen fertility and abiotic stresses management in cotton crop: A review. Environ. Sci. Pollut. Res. 2017, 24, 14551-14566. [CrossRef] [PubMed]

13. Alitabar, R.A.; Salimbeck, R.; Alishah, O.; Andarkhor, S.A.A. The effects of nitrogen and row spacing on growth and yield of cotton varieties. Int. J. Agric. Res. Rev. 2013, 3, 120-125. [CrossRef]

14. Ayissa, T.; Kebedeb, F. Effect of nitrogenous fertilizer on the growth and yield of cotton (Gossypium hirsutum L.) varieties in middle Awash, Ethiopia. J. Arid. Land 2011, 4, 248-258.

15. Dong, H. Effect of nitrogenous fertilizer strategies on the nitrogen accumulation in cotton field soil and cotton functional leaves. Cotton Sci. 2009, 1, 10.

16. Hu, M.; Tian, C.; Ma, Y.; Zhao, Z.; Wang, L. The relations between soil/plant tissue nitrate-N concentration and cotton yield or other related factors. Acta Agric. Boreali Occident. Sin. 2001, 11, 128-131. (In Chinese with English Abstract)

17. Tewolde, H.; Fernandez, C.J.; Foss, D.C.; Unruh, D. Critical petiole nitrite-nitrogen for lint yield and maturity in pima cotton. Agron. J. 1995, 87, 223-227. [CrossRef]

18. Zhang, H.; Zhu, Y.; Cao, W.; Zhou, Z.; Zhang, Z. A dynamic knowledge model for nitrogen and water management of cotton. Chin. J. Appl. Ecol. 2004, 15, 777-781.

19. Saleem, M.F.; Bilal, M.F.; Awais, M.; Shaid, M.Q.; Anjum, S.A. Effect of nitrogen on seed cotton yield and fiber quality of cotton cutivars. J. Anim. Plant Sci. 2010, 20, 23-27.

20. Rosolem, C.A.; Van, L.; Mellis, V. Monitoring nitrogen nutrition in cotton. Rev. Bras. Ciênc. Solo 2010, 34, 1601-1607. [CrossRef]

21. Shen, Y.; Li, S.; Chen, Y. Estimation of regional irrigation water requirement and water supply risk in the arid region of Northwestern China 1989-2010. Agric. Water Manag. 2013, 128, 55-64. [CrossRef]

22. Dagdelen, N.; Basal, H.; Yilmaz, E.; Gurbuz, T.; Akcay, S. Different drip irrigation regimes affect cotton yield, water use efficiency and fiber quality in western Turkey. Agric. Water Manag. 2009, 96, 111-120. [CrossRef]

23. Devkota, M.; Martius, C.; Lamers, J.P.A.; Sayre, K.D.; Devkota, K.P.; Vlek, P.L.G. Tillage and nitrogen fertilization effects on yield and nitrogen use efficiency of irrigated cotton. Soil Till. Res. 2013, 134, 72-82. [CrossRef]

24. Aujla, M.S.; Thind, H.S.; Buttar, G.S. Cotton yield and water use efficiency at various levels of water and $\mathrm{N}$ through drip irrigation under two methods of planting. Agric. Water Manag. 2005, 71, 167-179. [CrossRef]

25. Schroeder, J.; Neeteson, O.; Oenema, M. Does the crop or soil indicate how to save nitrogen in maize production?-Reviewing the state of the art. Field Crop Res. 2000, 66, 151-164. [CrossRef]

26. Bundy, L.G.; Andraski, T.W. Diagnostic tests for site-specific nitrogen recommendations for winter wheat. Agron. J. 2004, 96, 608-614. [CrossRef]

27. Spellman, D.E.; Rongni, A.; Westfall, D.G. Pre-sidedress nitrate soil testing to manage nitrogen fertility in irrigated corn in a semi-arid environment. Commun. Soil Sci. Plant Anal. 1996, 27, 561-574. [CrossRef]

28. Wang, K.; Li, S.; Cao, L.; Song, G.; Chen, G.; Cao, S. A preliminary study on dynamics and models of N, P, K absorption in high yield cotton in Xinjiang. Sci. Agric. Sin. 2003, 36, 775-780. (In Chinese with English Abstract)

29. Ibragimov, N.; Evett, S.R.; Esanbekov, Y.; Kamilov, B.S.; Mirzaev, L.; Lamers, J.P.A. Water use efficiency of irrigated cotton in Uzbekistan under drip and furrow irrigation. Agric. Water Manag. 2007, 90, 112-120. [CrossRef] 
30. Cabrera, M.L.; Kissel, D.E. Evaluation of a method to predict nitrogen mineralized from soil organic matter under field conditions. Soil Sci. Soc. Am. J. 1988, 52, 1071-1076. [CrossRef]

31. Constable, G.A.; Bange, M.P. The yield potential of cotton (Gossypium hirsutum L.). Field Crops Res. 2015, 182, 98-106. [CrossRef]

32. Ali, H.; Hameed, R.A. Growth, yield and yield components of American cotton (Gossypium hirsutum L.) as affected by cultivars and nitrogen fertilizer. Int. J. Eng. Sci. 2011, 2, 30. 